Ribogospod. nauka Ukr., 2015; 3(33): 46-54

DOI: $10.15407 /$ fsu2015.03.046

UDC 574.64:597.08 (285.33+26)

\title{
ORGANOCHLORINE PESTICIDES IN FISH OF THE KILIYA DELTA OF THE DANUBE (2003-2005)
}

Yu. Sytnik, sytnik yu@ukr.net, Institute of Hydrobiology of NAS of Ukraine, Kyiv M. Mardarevych, $\underline{m}$ miroslaw@YAHOO.com, Institute of Hydrobiology of NAS of Ukraine, Kyiv

T. Bersan, tatyana bersan@mail.ru, Institute of Fisheries NAAS, Kyiv

Purpose. Identification and analysis of the content of organochlorine pesticides (OCP) in organs and tissues of benthivorous and predatory fish species of the Kiliya delta of the Danube (Eastern mouth) and their comparison with previous years.

Methodology. The analysis of the samples of aquatic organisms for the content of residual organochlorine pesticides was carried out by gas-liquid chromatography (GLH) based on a unified methodology. The chromatographic analysis was carried out on the gas chromatograph "Color 5" with electron capture detector at the Institute of Hydrobiology of the National Academy of Sciences of Ukraine.

Findings. The effect of stable organochlorine pesticides on aquatic organisms is characterized by marked persistence in the environment and by high ability for migration and accumulation on different levels of food chains in aquatic ecosystems.

The continuous presence of OCP in all investigated organs and tissues of selected species with the presence of a certain amount of fat and consequently, the fixation of residual organochlorine pesticides. Among benthivorous fishes, the content of OCP in organs and tissues (total) is as follows: vimba $\rightarrow$ roach $\rightarrow$ wild carp $\rightarrow$ bream $\rightarrow$ gibel carp. Among the predators: asp $\rightarrow$ perch $\rightarrow$ European catfish $\rightarrow$ pikeperch.

Originality. Recently, a significant number of scientists all around the world returns to the problem of the accumulation and distribution (redistribution) of OCP in the components of aquatic ecosystems. This is associated with certain threats to the environment and human health, that could lead to negative consequences as a result of the consumption of fish as the highest trophic level in fresh waters of Ukraine.

Practical value. The obtained data indicate that the major commercial fish species of the Kiliya delta of the Danube river contains residual quantities of pesticides. This indicates to the need for continuous hygienic and toxicological monitoring of fish caught and sold. There is a tendency that smaller amounts of OCP are accumulated in less active species benthivorous (bream, gibel carp) compared to active ones (vimba, roach, wild carp), and these patterns are confirmed to the current study.

Keywords: pollution, organochlorine pesticides (OCP), DDT and its metabolites, $\alpha$ - and $\gamma$-isomers of $\mathrm{HCH}$.

\section{PROBLEM STATEMENT AND ANALYSIS \\ OF LAST ACHIEVEMENTS AND PUBLICATIONS}

The Danube is the largest river in the Central and South-Eastern Europe, which belongs to the Black Sea basin. By its length and catchment area, the Danube is the second river in Europe after the Volga. Only small part of the Danube River $(169 \mathrm{~km})$ goes across the territory of Ukraine - from Reni to its mouth. Approaching the Black Sea, the river, upstream Romanian city Tulcha, is divided into three branches:

(C) Yu. Sytnik, M. Mardarevych, T. Bersan, 2015 
Kiliyskyi, Sulynkyi, and Georgiivs'kyi. Water volume in the Danube delta is divided as follows: Kiliyskyi branch - 58\%, Sulinskiy branch - 19\%, Georgiivskyi branch $23 \%$. The most high water of them, Kiliyskyi branch $\left(129 \mathrm{~km}^{3} /\right.$ year $)$, goes along the border territory of Romania and Ukraine [1].

Lately, high number of scientists all over the world turns again to the studies the problem of organochlorine pesticide (OCP) accumulation and distribution (redistribution) in the components of aquatic ecosystems [6-8].

\section{HIGHLIGHT OF THE EARLIER UNRESOLVED PARTS OF THE GENERAL PROBLEM. AIM OF THE STUDY}

For a long enough period of time, especially in 1980-1990-ies, scientific circles and general public of Ukraine artificially supported the idea that the problems of organochlorine pollutants for the environment does not exist anymore and applied pesticides disintegrated virtually completely. First studies of the content of DDT and its metabolites in the mouth part of the Danube were carried out in May 1972 by scientists of the Department of Radiation and Chemical Biology of the Institute of the Biology of South Seas of the National Academy of Sciences of Ukraine [9]. In 1970-80-ies, DDT was the main pollutant of the Danube, while its quantity significantly decreased in 1990-ies. At the same time, there was an increase in $\mathrm{HCH}$ concentrations [2, 5].

The results of studies carried out at the of XX and beginning of XXI centuries showed that the part of water samples in the Danube contained the residues of organochlorine pesticide or the products of their decomposition - metabolites, at quantities significantly lower than the maximum allowable concentrations, but virtually all the time. E.g., the concentration of $\alpha-\mathrm{HCH}$ in the Danube water varied from 0 to $0.000141 \mathrm{mg} / \mathrm{dm}^{3}, \gamma-\mathrm{HCH}$ - from 0 to $0.000117 \mathrm{mg} / \mathrm{dm}^{3}$, DDT - from 0 to $0.000672 \mathrm{mg} / \mathrm{dm}^{3}, \mathrm{DDE}$ - from 0 to $0.00008 \mathrm{mg} / \mathrm{dm}^{3}$. At the same time, no pesticide content was detected in $62-69.4 \%$ of samples [3].

OCP is a problem of the pollution of virtually all rivers both small and large. Last studies carried out in the Dnieper River basin found stable organochlorine pesticides and their metabolites in all examined samples of organs and tissues of aquatic invertebrates and fish [4].

The levels of OCP accumulation are different for different aquatic species and different types of hydroecosystems, however, they are recorded everywhere and did not disintegrated or degraded at all and are continuously redistributed along hydroecosystem components by accumulating in fish as the highest trophic component in freshwaters of Ukraine [10].

It is known [5] that the residues of pesticides in aquatic organisms can act both directly and cause remote toxic consequences (genetic, teratogenic, etc.). If threshold concentrations of pesticides are present in fish, their cumulative actions with heavy metals, other toxic and radioactive substances can have severe effects. During spawning period, as a result of the mobilization of fat depots, earlier accumulated OCPs will pass to blood that will lead to the intoxication of fish and their offspring. The presence of pesticides in fish as food products of humans can result in negative effects on health. 
SanPiN 42-123-4540-87 currently acting on the territory of Ukraine regulates the sanitary norms of pesticide content in food products. According to them, the total content of hexachlorocyclohexane isomers should not exceed $0.03 \mathrm{mg} / \mathrm{kg}$ for freshwater fish, while for DDT and its metabolites $-0.3 \mathrm{mg} / \mathrm{kg}$.

\section{MATERIALS AND METHODS}

The work is based on the results of field studies, which were carried out by the Institute of Hydrobiology of Ukraine of the National Academy of Sciences and Institute of Fisheries of the National Academy of Agrarian Sciences in the Kiliya delta of the Danube. Samples were taken in summer period of 2003 and 2005, in particular in the Eastern mouth. In total, 205 samples of fish organs and tissues were taken. The analysis of fish samples for the content of residual OCPs was carried out using gas-liquid chromatography (GLC) according the unified technique. GLC is based on the recovery of OCPs from biological samples by the extraction with organic solvents and following refining of the obtained extracts depending on the content of extracting substances. In the case of the high content of the latters, refining was carried out using sulfuric acid saturated with anhydrous sodium sulfate. We used the chromatography with aluminum oxide or ACK silica gel columns, the chromatographic analysis was carried on gas chromatograph "Color-5" with electrone capture detector at the Institute of Hydrobiology. Detection sensitivity for the biosubstrate was $1 \times 10^{-3} \mathrm{mg} / \mathrm{kg}$ of wet weight.

\section{STUDY RESULTS AND THEIR DISCUSSION}

Stable organochlorine pesticides (OCP), which pass to water bodies, ultimately accumulate in different components of aquatic ecosystems but mainly concentrate in hydrobionts, especially in fish. They become the carriers of stable toxicants and at the same time the biomonitors of the state of the water body. For assessing the ecologicaltoxicological situation, determining the content of stables pesticides, which migrate in aquatic environment, the degree of their effects on aquatic organisms, it is important to know the levels of their accumulation in different components of aquatic ecosystem, their distribution in the tissues and organs hydrobiont and especially fish. The accumulation of stable pesticides in the organs and tissues of hydrobionts and the tendency of their transfer across throphic chains is an additional factor, which increases the ecological risk of water pollution.

Stable pesticides were found in all samples of different fish species and other hydrobionts. Stable organochlorine pesticides in the examined samples were represented by DDT and its metabolites o.n.1 - DDE and n.n.1 - DDE; o.n.1 - DDE and n.n.1 - DDD; o.n.1 - DDT and n.n.1 - DDT; $(\alpha-$ and $\gamma$-isomers of hexachlorocyclohexane $(\mathrm{HCH})$, the contents of which are represented as a total amount. The prevalence of metabolites indicates on the fact that there is a DDT degradation process, while the presence of $\mathrm{HCH}$ is related to the continued use of it in agriculture of some countries of the Danube basin $[6,7]$.

Figures 1-8 show the results of the studies carried out on the Eastern mouth of the Kiliya delta of the Danube river (one of the Starostambul mouth located east to the Black Sea) in August 2003 [6, 7]. 


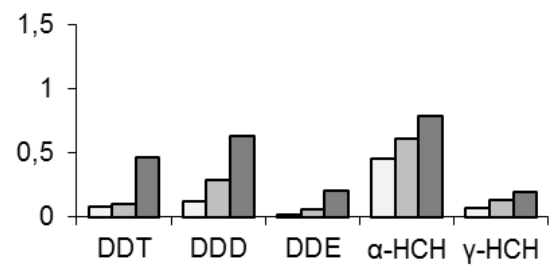

Fig. 1. OCP content in the organs and tissues of gibel carp

amuscles aliver abrain

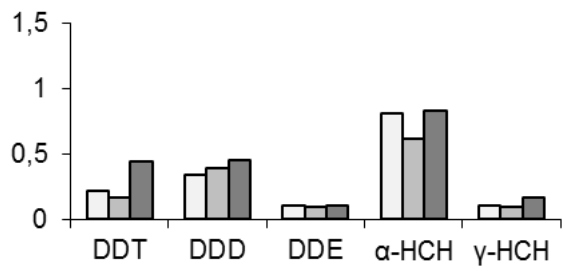

Fig. 3. OCP content in the organs and tissues of wild carp

口muscles aliver abrain

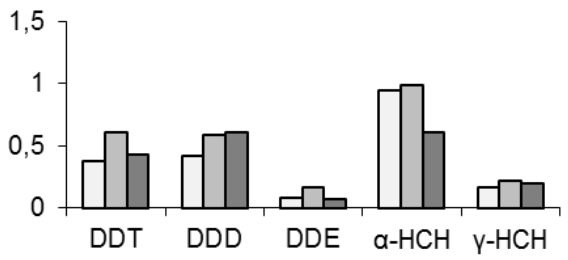

Fig. 5. OCP content in the organs and tissues of vimba

口muscles aliver abrain

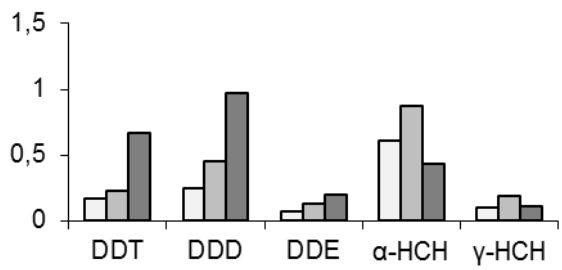

Fig. 7. OCP content in the organs and tissues of pikeperch

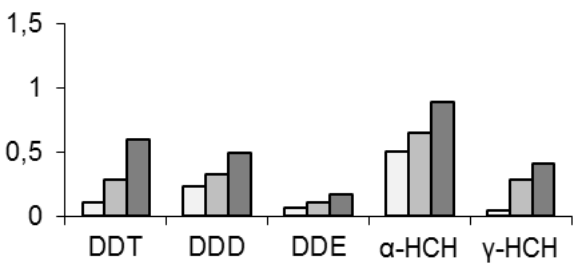

Fig. 2. OCP content in the organs and tissues of bream

口muscles aliver abrain

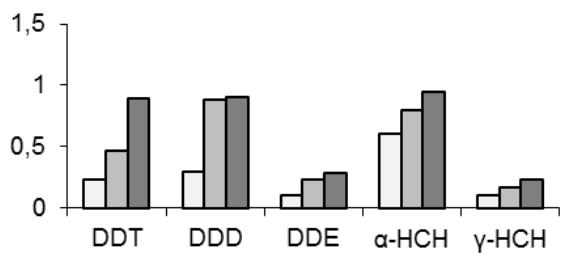

Fig. 4. OCP content in the organs and tissues of roach

amuscles aliver abrain

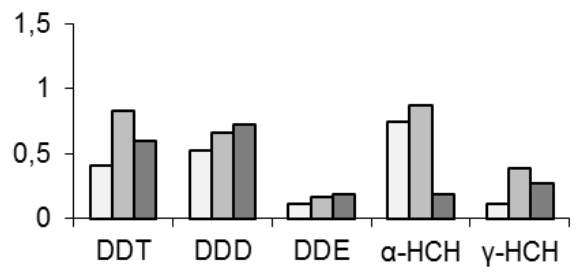

Fig. 6. OCP content in the organs and tissues of European catfish

amuscles aliver abrain

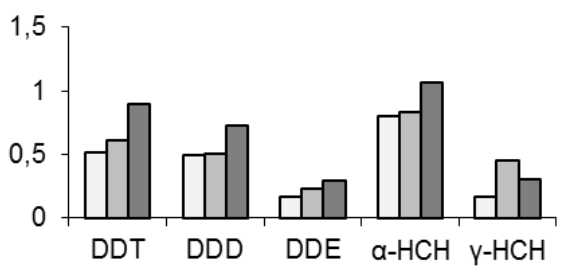

Fig. 8. OCP content in the organs and tissues of asp 
By the level of accumulation of stable toxicants, the first top position is occupied by predators - pikeperch, pike, perch, asp. There is no legalized normative values of OCP content in fish from the point of view of their biological hazard for fish. Experimental works and observations during mass kill of fish in the Dnieper reservoirs [5] show that such accumulation in stress situations (e.g., in temperature extremes, spawning, etc.) can result in fish intoxication and kill, while chronic contamination in gradual reduction in the level of metabolic processes, increases in parasite infestations and infectious diseases.

The provided data show that the main commercial fish species of the Kiliya delta of the Danube contain high enough residual quantities of organochlorine pesticides. It indicates on the necessity for continued hygienic and toxicological monitoring of fish caught and sold. The carried out studies allow providing insight into current ecologicaltoxicological situation of the Kiliya delta of the Danube. Currently, there is a clear picture of the pollution of the studied aquatic ecosystems with stable pesticides (OCP) resulting in the accumulation of toxicants in aquatic biota, especially in spring-summer period.

The materials of the study allow attesting continuous presence of OCP in all examined fish tissues. The typical sign of the examined tissues is the presence of certain amount of fat (muscles, liver). Vimba has especially high fat content in all tissues and as a result we observed the highest quantities of OCP in this species. As a whole, there is tendency of OCP content for all studied species: muscles $>$ liver $>$ brain $>$ internal fat (with some exceptions). The same tendencies were described earlier by some authors $[2,5,10]$.

Among benthivorous fish (Fig. 1-5), the following tendency for OCP content in fish tissues and organs is observed (pooled values): vimba $\rightarrow$ roach $\rightarrow$ wild carp $\rightarrow$ bream $\rightarrow$ gibel carp. Among predators (Fig. 6-8): asp $\rightarrow$ perch $\rightarrow$ European catfish $\rightarrow$ pikeperch. Perch were the youngest and smallest fish examined. Earlier [2], a tendency was observed that lower OCP levels accumulate in less active benthivorous fish (bream, gibel carp) compared to more active ones (vimba, roach, wild carp). The results of our studies of 2005 (Table 1) confirms these tendencies.

In 2005, the studies were continued. Tables 1 and 2 show the results of the studies carried out in the Eastern mouth of the Kiliya delta of the Danube in August 2005.

Table 1. OCP content in organs and tissues of benthivorous fish of the Kiliya delta of the Danube river (Eastern mouth), 20.08-25.08.2005, $M, n=4, \mathrm{mg} / \mathrm{kg}$ of wet weight

\begin{tabular}{|c|c|c|c|c|c|c|}
\hline Species & Organs or tissues & DDT & DDD & DDE & $\alpha-\mathrm{HCH}$ & $\mathrm{p}-\mathrm{HCH}$ \\
\hline \multirow{3}{*}{ Gibel carp } & Muscles & 0.07 & 0.10 & 0.03 & 0.45 & 0.08 \\
\hline & Liver & 0.12 & 0.25 & 0.07 & 0.60 & 0.10 \\
\hline & Brain & 0.40 & 0.60 & 0.25 & 0.75 & 0.25 \\
\hline \multirow{3}{*}{ Bream } & Muscles & 0.12 & 0.25 & 0.08 & 0.52 & 0.07 \\
\hline & Liver & 0.32 & 0.30 & 0.15 & 0.61 & 0.24 \\
\hline & Brain & 0.53 & 0.55 & 0.21 & 0.80 & 0.42 \\
\hline \multirow{3}{*}{ Wild carp } & Muscles & 0.20 & 0.36 & 0.14 & 0.74 & 0.15 \\
\hline & Liver & 0.19 & 0.43 & 0.25 & 0.52 & 0.12 \\
\hline & Brain & 0.46 & 0.49 & 0.17 & 0.75 & 0.14 \\
\hline
\end{tabular}


Continued table 1

\begin{tabular}{||c|c|c|c|c|c|c||}
\hline Species & Organs or tissues & DDT & DDD & DDE & $\boldsymbol{\alpha}$-HCH & $\boldsymbol{\gamma}$-HCH \\
\hline \multirow{3}{*}{ Roach } & Muscles & 0.20 & 0.32 & 0.15 & 0.54 & 0.40 \\
\cline { 2 - 5 } & Liver & 0.34 & 0.89 & 0.28 & 0.68 & 0.16 \\
\cline { 2 - 5 } & Brain & 0.80 & 0.79 & 0.32 & 0.91 & 0.20 \\
\hline
\end{tabular}

Table 2. OCP content in organs and tissues of predatory fish of the Kiliya delta of the Danube river (Eastern mouth), 20.08-25.08.2005, $M, n=4, \mathrm{mg} / \mathrm{kg}$ of wet weigh

\begin{tabular}{|c|c|c|c|c|c|c|}
\hline Species & Organs or tissues & DDT & DDD & DDE & $\alpha-\mathrm{HCH}$ & $\gamma-\mathrm{HCH}$ \\
\hline Perch & Muscles & 0.40 & 0.65 & 0.32 & 1.16 & 0.20 \\
\hline \multirow{3}{*}{ Pikeperch } & Muscles & 0.35 & 0.45 & 0.13 & 0.83 & 0.14 \\
\hline & Liver & 0.56 & 0.63 & 0.21 & 0.87 & 0.18 \\
\hline & Brain & 0.45 & 0.72 & 0.12 & 0.57 & 0.16 \\
\hline \multirow{3}{*}{$\begin{array}{c}\text { European } \\
\text { catfish }\end{array}$} & Muscles & 0.45 & 0.59 & 0.13 & 0.70 & 0.15 \\
\hline & Liver & 0.82 & 0.69 & 0.19 & 0.85 & 0.36 \\
\hline & Brain & 0.64 & 0.79 & 0.21 & 0.25 & 0.16 \\
\hline
\end{tabular}

Comparing the obtained results with the previous ones (Fig. 1-8) [6, 7], we can say that that the OCP contents did not change significantly for such a short period of time.

\section{CONCLUSION AND PERSPECTIVES OF FURTHER DEVELOPMENT}

The results of the performed studies indicate on the continuous presence and circulation of OCPs in the components of the hydroecosystem of the Ukrainian part of the Danube river, including Kiliya delta. The organs and tissues of all examined fish contained OCPs. The same as in previous years, the highest OCP content was observed in fat-containing organs and tissues. The tendency of their distribution in fish did not change.

The analysis of scientific literature and materials of own investigations allows drawing a conclusion that the most toxic stable organochlorine pesticides for hydrobionts are those, which are characterized by the highest persistence in the environment and high ability to migrate and accumulate in the different links of the food web of aquatic ecosystems.

\section{BIBLIOGRAPHY}

1. Гидроэкология украинского участка Дуная и сопредельных водоемов / [Харченко Т. А., Тимченко В. М., Ковальчук А. А. и др.]. - К. : Наук. думка, 1993. - $328 \mathrm{c}$.

2. Маслова О. В. Аккумуляция хлорорганических пестицидов в рыбах и макробеспозвоночных / Маслова О. В., Комаровский Ф. Я., Брагинский Л. П. // Гидроэкология украинского участка Дуная и сопредельных водоемов - К. : Наук. думка, 1993. - 225 с.

3. Лозовіцький П. С. Специфічні речовини токсичної дії у воді річки Дунай / П. С. Лозовіцький // Екологічні науки. - 2012. — № 6. - С. 21-34.

4. Экологическое состояние трансграничних участков рек Днепра на территории Украины / [ред. А. Г. Васенко, С. А. Афанасьев]. - К. : Академпериодика, 2002. -355 c. 
5. Брагинский Л. П. Пестициды и жизнь водоемов / Брагинский Л. П. - К. : Наук. думка, 1972. - 224 с.

6. Ситник Ю. М. Вміст хлорорганічних пестицидів у тканинах риби Кілійської дельти Дунаю / Ю. М. Ситник, О. М. Арсан, Д. А. Засєкін // Науковий вісник Львівської національної академії ветеринарної медицини імені С. 3. Гжицького. - 2007. - Т. 9, № 1 (32). - С. 356-361.

7. Ситник Ю. М. Вміст ДДТ і ГХЦГ в органах і тканинах риб Кілійської дельти Дунаю на початку XXI століття / Ю. М. Ситник, О. М. Арсан, Д. А. Засєкін // Zoocenosis-2011. Біорізноманіття та роль тварин в екосистемах : VI Міжнародна наукова конференція : тези доп. - Дніпропетровськ : Вид-во ДНУ, 2011. - С. 126-129.

8. Осокина Н. П. Содержание хлорорганических пестицидов в объектах окружающей среды устья и среднего течения р. Дунай / Н. П. Осокина, А. Ю. Метропольский // Причорноморський екологічний бюлетень. - 2006. — № 3/4 (1). - С. 150-155.

9. Радиохемоэкология Черного моря / [ред. Г. Г. Поликарпов, Н. С. Рисик]. К. : Наук. думка, 1977. - 119 с.

10. Врочинський К. К. Пестициди і охорона водних ресурсів / Врочинський К. К. — К. : Урожай, 1987. — 160 с.

\section{REFERENCES}

1. Kharchenko, T. A., Timchenko, V. M., \& Koval'chuk, A. A., et al. (1993). Gidroekologiya ukrainskogo uchastka Dunaya i sopredel'nykh vodoemov. Kiev : Naukova dumka.

2. Maslova, O. V., Komarovskiy, F. Ya., \& Braginskiy, L. P. (1993). Akkumulyatsiya khlororganicheskikh pestitsidov $v$ rybakh $i$ makrobespozvonochnykh. Gidroekologiya ukrainskogo uchastka Dunaya i sopredel'nykh vodoemov. Kiev : Naukova dumka.

3. Lozovitskyi, P. S. (2012). Spetsyfichni rechovyny toksychnoi dii u vodi richky Dunai. Ekolohichni nauky, 6, 21-34.

4. Vasenko, A. G., \& Afanas'eva, S. A. (Eds.). (2002). Ekologicheskoe sostoyanie transgranichnikh uchastkov rek Dnepra na territorii Ukrainy. Kiev : Akademperiodika.

5. Braginskiy, L. P. (1972). Pestitsidy i zhizn' vodoemov. Kiev : Naukova dumka.

6. Sytnyk, Yu. M., Arsan, O. M., \& Zasiekin, D. A. (2007). Vmist khlororhanichnykh pestytsydiv u tkanynakh ryby Kiliiskoi delty Dunaiu. Naukovyi visnyk Lvivskoi natsionalnoi akademii veterynarnoi medytsyny imeni S.Z. Hzhytskoho, 9, 1 (32), 356-361.

7. Sytnyk, Yu. M., Arsan, O. M., \& Zasiekin, D. A. (2011). Vmist DDT i HKhTsH v orhanakh i tkanynakh ryb Kiliiskoi delty Dunaiu na pochatku XXI stolittia. VI Mizhnarodna naukova konferentsiia Zoocenosis-2011. Bioriznomanittia ta rol tvaryn v ekosystemakh. Dnipropetrovsk, 126-129.

8. Osokina, N. P., \& Metropol'skiy, A. Yu. (2006). Soderzhanie khlororganicheskikh pestitsidov v ob"ektakh okruzhayushchey sredy ust'ya i srednego techeniya $\mathrm{r}$. Dunay. Prichornomors'kiy ekologichniy byuleten', 3/4 (1), 150-155.

9. Polikarpov, G. G., \& Risik, N. S. (Eds.). (1977). Radiokhemoekologiya Chernogo morya. Kiev : Naukova dumka.

10. Vrochynskyi, K. K. (1987). Pestytsydy i okhorona vodnykh resursiv. Kyiv : Urozhai. 


\section{ХЛОРОРГАНІЧНІ ПЕСТИЦИДИ У РИБАХ КІЛІЙСЬКОЇ ДЕЛЬТИ ДУНАЮ (2003-2005 РР.)}

Ю. М. Ситник, sytnik yu@ukr.net, Інститут гідробіології НАН України, м. Київ М. Г. Мардаревич, $\underline{m}$ miroslaw@YАНОО.com, Інститут гідробіології НАН України, м. Київ

Т. О. Берсан, tatyana bersan@mail.ru, Інститут рибного господарства НАAН, м. Київ

Мета. Визначення та аналіз вмісту хлорорганічних пестицидів (ХОП) у органах та тканинах бентофагів та хижих видів риб Кілійської дельти Дунаю (гирло Восточне) та порівняння їх з результатами попередніх років.

Методика. Проведення аналізів проб гідробіонтів на вміст залишкових хлорорганічних пестицидів проводили за допомогою газорідинної хроматографії (ГРХ) за єдиною методикою. Хроматографічний аналіз проводився на газовому хроматографі “Цвет-5» з електроннозахоплювальним детектором в Інституті гідробіології Національної академії наук України.

Результати. Стійкі хлорорганічні пестициди, вирізняються вираженою персистентністю у навколишньому середовищі і характеризуються високою здатністю до міграції та накопичення у різних ланках трофічних ланцюгів водних екосистем.

У досліджуваних органах і тканинах відібраних видів риб, за наявності певної кількості жиру - фіксація залишкової кількості хлорорганічних пестицидів. Серед бентофагів за вмістом ХОП в органах і тканинах (сумарно) ряд виглядає наступним чином (у порядку зростання): рибець $\rightarrow$ тарань $\rightarrow$ сазан $\rightarrow$ лящ $\rightarrow$ карась сріблястий. Серед хижаків: білизна (жерех) $\rightarrow$ окунь $\rightarrow$ сом $\rightarrow$ судак.

Наукова новизна. В останні роки багато вчених у всьому світі знову повертається до вивчення проблеми накопичення та розподілу (перерозподілу) ХОП у компонентах водних екосистем. Це пов'язано з наявністю певних загроз для довкілля та здоров'я людини, що може призвести до негативних наслідків у результаті споживання риби як вищої трофічної ланки прісноводних екосистем України.

Практична значимість. Отримані дані свідчать про те, що основні промислові види риб Кілійської дельти Дунаю містять залишкову кількість пестицидів. Це вказує на необхідність проведення постійного гігієнічного та токсикологічного контролю риби, що виловлюється та реалізується. Відмічена закономірність нижчого рівня накопичення ХОП у менш рухливих видів бентофагів (лящ, карась сріблястий) порівняно із активнішими (рибець, тарань, сазан), підтверджуться даними цього дослідження.

Ключові слова: забруднення, хлорорганічні пестициди (ХОП), ДДТ та його метаболіти, $\alpha$ - і ү-ізомери ГХЦГ.

\section{ХЛОРОРГАНИЧЕСКИЕ ПЕСТИЦИДЫ В РЫБАХ КИЛИЙСКОЙ ДЕЛЬТЫ ДУНАЯ (2003-2005 ГГ.)}

Ю. М. Сытник, sytnik yu@ukr.net, Институт гидробиологии НАН Украины, г. Киев М. Г. Мардаревич, $\mathrm{m}$ miroslaw@YAHOO.com, Институт гидробиологии НАН Украины, г. Киев

T. А. Берсан, tatyana bersan@mail.ru, Институт рыбного хозяйства НАAН, г. Киев

Цель. Определение и анализ содержания хлорорганических пестицидов (ХОП) в органах и тканях бентофагов и хищных видов рыб Килийской дельты Дуная (устье Восточное) $и$ сравнение их с результатами предыдущих лет.

Методика. Проведение анализов проб гидробионтов на содержание остаточных хлорорганических пестицидов проводили с помощью газожидкостной хроматографии (ГЖХ) по единой методике. Хроматографический анализ проводился на газовом хроматографе 
«Цвет-5» с электронно-захватывающим детектором в Институте гидробиологии Национальной академии наук Украины.

Результаты. Стойкие хлорорганические пестициды, отличающиеся выраженной персистентностью в окружающей среде, характеризуются высокой способностью $\kappa$ миграции и накоплению в разных звеньях трофических цепей водных экосистем.

В исследуемых органах и тканях отобранных видов рыб, при наличии определенного количества жира - фиксация остаточного количества хлорорганических пестицидов. Среди бентофрагов по содержанию хОП в органах и тканях (суммарно) ряд выглядит следующим образом (в порядке возрастания): рыбец $\rightarrow$ тарань $\rightarrow$ сазан $\rightarrow$ лещ $\rightarrow$ серебряный карась. Среди хищников: белизна (жерех) $\rightarrow$ окунь $\rightarrow$ сом $\rightarrow$ судак.

Научная новизна. В последние годы множество ученых во всем мире снова возвращаются к изучению проблемы накопления и распределения (перераспределения) ХОП в компонентах водных экосистем. Это связано с наличием определенных угроз для окружающей среды и здоровья человека, что может привести к негативным последствиям, в результате потребления рыбы как высшего трофического звена пресноводных экосистем украины.

Практическая значимость. Полученные данные свидетельствуют о том, что основные промысловые виды рыб Килийской дельты Дуная содержат остаточное количество пестицидов. Это указывает на необходимость проведения постоянного гигиенического и токсикологического контроля вылавливаемой и реализуемой рыбы. Отмеченная закономерность - меньшие количества хоП накапливаются у менее подвижных видов бентофагов (лещ, карась серебристый) по сравнению с активными (рыбеи, тарань, сазан) - подтверждается данными настоящего исследования.

Ключевые слова: загрязнение, хлорорганические пестициды (ХОП), ДДТ и его метаболиты, $\alpha$ - и ү-изомеры ГХЦГ. 